\title{
Romanian welfare state between excess and failure
}

\author{
Cristina Ciuraru-Andrica, "Vasile Alecsandri” University from Bacau, Romania
}

\begin{abstract}
:
Timely or not, our issue can bring back to life some prolific discussions, sometimes diametrical. We strike the social assistance, where, at this moment, is still uncertain if, once unleashed the excess, the failure will come inevitably or there is a "Salvation Ark". However, the difference between the excess and the failure of the welfare state is almost intangible, the reason of his potential failure being actually the abuses made until the start of depression.
\end{abstract}

\section{Key words:}

Welfare state, social assistance, the exceess of the welfare state, the failure of the welfare state

\section{Introduction}

At the beginning, we must say that, sometimes, inappropriately and unjustifiable, the social protection and, especially, the social assistance, like parts of social political, receive a bad connotation, because they are pressing the State against some economical objectives. In reality, these expenses are stringencies in society and proceed from a function of the State: to take care of his citizens. Moreover, it is known that, especially, a depression time requires a realistic effort to offset "the costs of change" that the population must to bear. That is way, in this context of living it is nearly justified and legitimate, a big rate of social protection expenses in GDP and also in all public expenditure. Unfortunately, this is not quite the thing that is happening in our society: in this time of crisis the public expenditure, and mostly with social protection, are maximally reduced. Why? Because the public financial resources are more and more diminished and even not enough. This problem should not concern us if we were not, in some way or another, depending on State. It looks like, just right now, in crisis time, he fails to fulfill own vocation, quite when his function, mentioned above, should be most visible.

\section{The Romanian welfare state: excess or failure?}

However, there are still voices which maintain that social protection is extreme in Romania. Such conclusion is probably founded on the wrong association of it with the social assistance, last one being just one way to accomplish the public social protection, using the public social expenditure.

Even more, a recent study ${ }^{1}$ (2010, June) made by the Research Institute for Quality of Life: After 20 years: Options for Romania, show that, while the development countries invest more that $30 \%$ of GDP for social politics area (which includes social protection too), Romania invests only $16.4 \%$ of GDP, even less than the half of EU average, being below of all the transitional countries, EU members. The same situation is in the case of the rate of social expenditure in the public budget: $36.5 \%$ for Romania relative $55.9 \%$ EU average. So, the study underlines that the feedback of the Romanian Government to these problems is

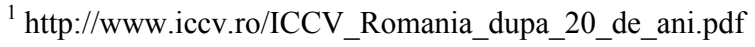


wrong again. By cutting the social budget: remunerations in education, health and social assistance, the pensions and other social benefits of some risk groups, the public budget will not raises the equilibrium. Instead these groups will support hardly the price of the crisis.

Therefore, is justified a higher rate of poverty in our country relative of other EU countries. This conclusion of the analysis, made by Research Institute for Quality of Life, may misleading the opinion that increasing the rate of social expenditure will eradicate the poverty and all social inequities still existent. But this increment must be efficiently made by having at the base a real growth of GDP which will allow an important allocation, to the public expenditure and to the social area, especially.

An overall view on this study reveals an aspect maybe less accepted by some people: the Romanian sector of public social expenditure is deficient. Such a conclusion is difficult in our daily context marked, on the contrary, by the solid motivations for privatization, especially in vital economical areas such as education and health, with negative consequences: increasing the social polarization, expanding the poor segment of population which will be condemned to a precarious education and health.

Then where is the excess?

Insufficient financing of social expenditure must be analyzed in its structure also, whereas at chapters such as education and health, it is indeed present and accepted. But a sensitive problem is the social assistance expenditure. Is this category under financed or here "the excess has found its home"?

Statistics show that the funds for social assistance are increasing more and more, obviously because the number of social assisted is bigger and the social benefits are more diversified. The evolution of the funds allocated for the social assistance is relevant (figure 1).

Figure no. 1 Social assistance expenditure in public budget vs. social assistance expenditure (in public and local budgets) in billion lei, right scale

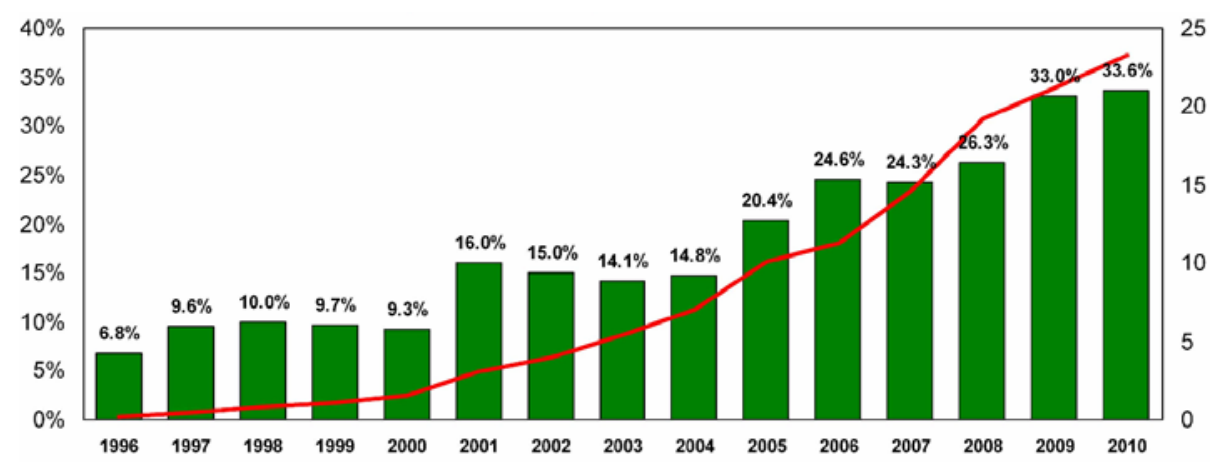

The source: www.businessday.ro

This situation makes us wonder whether such an increase is realistic or hide the abuses and intolerable business interests.

On the one hand, this seems paradoxical because is manifested simultaneously with an increase of GDP per capita, in the mentioned period, with more than $100 \%$. It's more than obvious that there were abuses, and social assistance is no longer strictly oriented to those who really need it. The situation is more tragic in the context in which, instead the issues from economic growth to be invested in infrastructure, schools, hospitals or save them for harder times, they have been directed to social causes "wrapped in a false sadness".

On the other hand, maintaining the poverty rate at the highest levels in Europe makes us believe that the social assistance costs are justified and moreover, required and unavoidable. Certainly not in their entirety, but for the most part, they are the effect of an acute poverty among Romanian citizens. 
So there was an excess where the social assistance was not needed but where it went though without "bother" someone. That is, until recently. Now, the "hand of the State" reach "the bottom of the bag" and that forced him "to cut without mercy" even from where would not be moral (in virtue of the principle of social solidarity which should remain constant even when scaffold collapses).

This circumspect context, in which is "juggling" with social assistance, created a new interpretation of present crisis. That is linked to the mistakes of the welfare state, sometimes irresponsible, assisting citizens equally irresponsible. Such abuses could "prepare and pave" the path to failure.

At a recent conference (2010, September 27) titled: "The failure of the welfare state. Market solutions to economic crisis", Professor Valeriu Stoica said that indeed we are witnessing at the failure of the welfare state. Why?

Paraphrasing him, it would be at least the following considerations ${ }^{2}$ :

1. encouraging those who do not work

In every election year, social assistance has turned into an opportunity to "grab votes" by promises, made to the mentioned category (large by the way), which have materialized sometimes, but with an unrealistic economic base and marked by the desire of political parties for power, violating public balance and breaking the limits. They have encouraged, obviously, inoccupation or at least inhibited any intention of the person to rise from its own situation.

2. increasing the number of public employees

The impressive growth of the number of public employees, from 900,000 in 1990 to $1,400,000$ on 1 January 2010, has burdened the State and focused his resources on this category. So, in addition to the impressive number of social assisted, the public employees also depend, in one way or another, by the State, being forced to pay, perhaps more than other categories, the consequences of a social assistance, sometimes forced, sometimes exaggerated.

3. discouraging those who still work

This consequence of the welfare state is derived from that one mentioned in paragraph 1 and is manifested in the migration of labor to gray or black sectors of the economy, or to other countries better rated, or even relocation companies in Bulgaria, for example.

4. obtaining higher, many and unfunded deficits

Even if, the programs presented, for gain the financing, were relevant and according to reality, once obtained the loan, its main purpose was to cover deficits and current expenses rather than investment. Therefore, the objectives were only partially fulfilled. So, as debtor, the welfare state has lost its credibility in front of his donors, because has become extremely uncertain its ability to satisfy the needs of a society more and more polarized, poor and dissatisfied, consuming more than produces. Worse is that Romania has become someway dependent on external funding, which bonding our future and draining it of its resources.

5. causing the government of those who do not work an do not pay taxes

The political parties have made many promises through programs that abound in social protection measures, only to get the power. This has led to ingrate situation that the rules are made not by the productive people. The price paid for winning such an electorate, with public money of course, is precisely this "troubled daily" which every citizen is forced to bear it. So the welfare state creates, deliberately, situations that require a deeper dependence on it, "creating poor", instead of promote politics for "social emancipation of citizens" ${ }^{3}$.

\footnotetext{
2 Valeriu Stoica, Eşecul statului asistenţial. Cauzele crizei economice, http://www.cadi.ro/index.php/vizualizare/articol/multimedia/352

3 http://www.observatorcultural.ro/Statul-asistential-sau-fabricantul-de-saraci*articleID_8567articles_details.html
} 
Among the causes listed above could more say that the failure of the welfare state is connect with its irresponsibility in handling tasks sometimes foreign of "his reason to exist" (taking over the huge debts of some private and public enterprises).

Then, the "infusion of populism" in the last period (of course promoted by politicians greedy for power) is "embedded" the false belief, among the citizens, that, whatever the performance of companies or of persons, the State has to give. Where? What sacrifices? It does not matter. The right for social assistance (mentioned even in the Constitution) has become a right sometimes "more equal than others" which is allowed without taking into account the real possibilities of economy. Thus, however the efficiency of austerity measures that must be taken (even if they incite the voters), they will never be accepted by citizens because "theirs wishes and expectations" must be satisfied by "the great State". Whether we admit or not, it is difficult to inhibit the mentality of Romanian people, for which the State is like a God that divides good and bad, and not like a manager of resources for the benefit of his citizens ${ }^{4}$.

A belief, which is becoming more evident today, is that the Romanian system of social assistance is out-of-date. Why? Because the public money is randomly threw, without certainly knowing that they reach in the right place. An example of "revival" of the system is promoted by some countries (in Latin America), where the social assistance benefits are strongly conditioned by human capital formation ${ }^{5}$. Thus help the social assisted to face the situations which make him a dependent of the State. That it should be the future of social assistance.

In this sense, the desire of Ludwig Erhard could give food for thought: "I want to affirm myself with my own power, I want to wear the risk of live, I want to be responsible for my destiny. You, The State, do only what it takes so I should be able to do all this. You, The State, don't worry about me, instead gives me the freedom and the needed resources so I be able to assure the destiny and the existence for me and my family" ${ }^{6}$.

A "picture" of the welfare state is illustrated by a very suggestive resemblance:

Welfare state is dealing with social assisted like a family who raises her children badly. She provides them food and home, but not guide them for a school performance, not underlines their qualities, not accustomed them with the effort. Assisted-persons are convinced that others (the State, in this case) are responsible for their lives. Both, the children badly raised and the social assisted, will have every reason to be dissatisfied with those who look only not to die of hunger and have a roof over their head. But the welfare state can provide less ${ }^{7}$.

\section{Conclusions}

There is still a chance for the welfare state?

If the answer is yes, the State should start by supporting what is really a priority at the moment for Romania, allocating resources properly and removing the obvious abuses (social, political, etc.) that "burden" both State and its citizens. Such a relevant screening and fully justified before the people can still give a chance for the welfare state. Thereby, the Romanian Government took the first step including in its Fiscal Budgetary Strategy for the period $2011-2013^{8}$, through the proposed austerity measures, ways to develop and diversify the social services for vulnerable groups, which are not covered by existing ones, and also to

\footnotetext{
${ }^{4}$ Idem $^{3}$

${ }^{5}$ Theodor Stolojan, Liberalizarea pieţei muncii şi reforma sistemelor de asigurări şi asistenţă socială, http://www.cadi.ro/index.php/vizualizare/articol/multimedia/352

${ }^{6} \mathrm{http}$ ://www.ronduldesibiu.ro/economie/Ludwig-Erhard-economia-sociala-piata/

${ }^{7} \mathrm{http}: / /$ www.observatorcultural.ro/Statul-asistential*articleID 5590-articles details.html

${ }^{8} \mathrm{http}: / /$ discutii.mfinante.ro/static/10/Mfp/strategbug/STRATEGIA_FB_27sept.pdf
} 
reduce the abuse of social assistance benefits. Of course, the promises are making, but to accomplish them ... however we never know.

Then, releasing the State from the public enterprises and some public services and engage them in the private sector can lead to the transformation of "irresponsible consumers of taxes" in the "payers taxes" by their efficiency and profitability ${ }^{9}$.

We all want prosperity, but do not forget that it is not magically created by the State. Paraphrasing Ludwig Erhard, prosperity for all and prosperity through competition are inseparable parts of the same whole. Prosperity for all is the main aim and prosperity through competition is the mean by which achieving the aim.

\section{Aknowledgements:}

"This work was supported by the European Social Fund in Romania, under the responsibility of the Managing Authority for the Sectoral Operational Programme for Human Resources Development 2007-2013 [grant POSDRU/CPP 107/DMI 1.5/S/78342]".

\section{References:}

1. Theodor Stolojan, Liberalizarea pieței muncii şi reforma sistemelor de asigurări şi asistenţă socială, http://www.cadi.ro/index.php/vizualizare/articol/multimedia/352 - accesat la 5.12.2010

2. Tom Palmer, The Welfare State, More Vulnerable to the Crisis, http://www.cadi.ro/index.php/vizualizare/articol/multimedia/352 - accesat la 6.12.2010

3. Valeriu Stoica, Eşecul statului asistenţial. Cauzele crizei economice, http://www.cadi.ro/index.php/vizualizare/articol/multimedia/352 - accesat la 4.12.2010

4. http://discutii.mfinante.ro/static/10/Mfp/strategbug/STRATEGIA_FB_27sept.pdf - accesat la 6.12 .2010

5. http://www.iccv.ro/ICCV_Romania_dupa_20_de_ani.pdf - accesat la 5.12.2010

6. http://www.observatorcultural.ro/Statul-asistential*articleID_5590-articles_details.html - accesat la 4.12 .2010

7. http://www.observatorcultural.ro/Statul-asistential-sau-fabricantul-de-saraci*articleID_8567articles_details.html - accesat la 4.12.2010

8. http://www.ronduldesibiu.ro/economie/Ludwig-Erhard-economia-sociala-piata/ - accesat la 5.12 .2010

\footnotetext{
9 Tom Palmer, The Welfare State, More Vulnerable to the Crisis, http://www.cadi.ro/index.php/vizualizare/articol/multimedia/352
} 